\title{
Внутрішньокишковий тиск при реконструктивно-відновних операціях у стомованих хворих
}

\begin{abstract}
Мета роботи: покращення результатів лікування хворих із хірургічною патологією ободової кишки шляхом розпрацювання і впровадження патогенетично обгрунтованого алгоритму лікування та техніки створення анастомозу, спрямованого на зниження частоти післяопераційних ускладнень.

Матеріали і методи. В групі з 30 пацієнтів вимірювали внутрішньокишковий тиск (ВКТ) у післяопераційному періоді. Під час операції, крім трансанального дренажу, який заводили вище анастомозу на 5-10 см, проводили трубку діаметром 0,5 см, кінець якої встановлювали на рівні товстокишкового анастомозу (ТКА). Вимірювання тиску проводили методом Вальдмана протягом 72 год із моменту операції, кожні 4 години. При цьому виконували 2 вимірювання - до і після промивання трансанального дренажу. При виконанні відновного втручання ТКА за розробленою методикою виконали - 17, ручний дворядний ТКА - 3 , апаратний ТКА - 10 хворим.

Результати досліджень та їх обговорення. Встановлено, що в післяопераційному періоді в ободовій кишці спостерігається зростання ВKТ (Р) протягом перших 24-36 год (t) в середньому до $(5,3 \pm 0,1)$ мм рт. ст., $з$ подальшим зниженням цього рівня протягом наступних 12-20 год до $(2,1 \pm 0,3)$ мм рт. ст. Через 20 хв після промивання трансанального дренажу і відходження “промивних вод” рівень ВКТ знижується в середньому на $(3,0 \pm 1,3)$ мм рт. ст. Це зниження утримувалося протягом $3-5$ год, після чого відбулося поступове зростання рівня ВКТ. При застосуванні традиційного дворядного анастомозу у 2 хворих відмічено в одному спостереженні неспроможність ТКА, у другому - анастомозит. ТКА розробленим способом виконано 17 хворим, апаратний TKA - 10 хворим, анастомозит розвинувся в одного пацієнта. Ускладнення траплялися переважно при застосуванні ручного традиційного шва (10 \%). У всіх хворих з розвиненими порушеннями загоєння анастомозу спостерігається підвищення ВКТ через 16-60 год до $(11,4 \pm$ 0,2) мм рт. ст., $з$ піком близько $(16,3-17,1)$ мм рт. ст., що спостерігалось аж до розвитку неспроможності анастомозу, з наступним різким зниженням ВКТ. При анастомозиті подібного зниження ВКТ не було. Мало значення не тільки стійке підвищення ВКТ з критичним рівнем до 16,3-17,1 мм рт. ст., а й тривалість впливу його протягом 12-18 год.
\end{abstract}

Ключові слова: внутрішньокишковий тиск; товстокишковий анастомоз; реконструктивна операція; стома.

\section{Постановка проблеми і аналіз останніх до-} сліджень та публікацій. Серед захворювань ободової кишки, які підлягають хірургічній корекції, пріоритетними за частотою та тяжкістю вважають злоякісні новоутворення ободової кишки, непухлинні процеси, такі, як дивертикульоз, доліхосигма, поліпоз, запальні захворювання товстої кишки, хронічний товстокишковий стаз, в тому числі стомовані хворі. Захворюваність на рак товстої кишки в Україні постійно зростає і вийшла на третє місце в структурі онкологічних захворювань [2]. Щорічно у світі занедужує 15-18 чоловік на 100 тисяч населення. Смертність при цій локалізації раку залишається високою і не виявляє тенденції до зниження. У США колоректальний рак $є$ причиною смерті 3,4 \% осіб загальної популяції і другий за частотою серед причин смерті [7]. При цьому однією з причин смерті $\epsilon$ неспроможність анастомозів у хірургії ободової кишки, яка складає 11-12 \% [1, 4, 6]. Серед чисельних факторів, які роблять свій внесок у неспроможність анастомозів при хірургії ободової кишки, слід віднести хірургічну техніку. В цілому, усі методи формування товстокишкових анастомозів можна розділити на ручні та апаратні [2]. При цьому дебати переваги однорядного проти дворяд- ного, ручного проти апаратного та переваги якого-небудь іншого методу та їх модифікації продовжуться до сьогодні. Водночас на сьогодні не отримано доказів переваги одного методу над іншим [1-3]. Навіть ідеально, з точки зору хірургічної техніки, виконане хірургічне втручання на ободовій кишці не виключає можливість розвитку неспроможності анастомозу. Хоча багато досліджень присвячено визначенню факторів ризику неспроможності, характер мікроциркуляції в зоні анастомозу, рівень забруднення, техніка формування, внутрішньопросвітний тиск, віддаль анастомозу від анального каналу, підготовка кишки, спосіб дренування черевної порожнини, достеменної відповіді на причину неспроможності не встановлено $[1,4,5]$.

Тому намагання покращити результати хірургічного лікування захворювань ободової кишки шляхом розпрацювання і впровадження нових способів формування анастомозів $є$ актуальним.

Мета роботи: покращення результатів лікування хворих із хірургічною патологією ободової кишки шляхом розпрацювання і впровадження патогенетично обгрунтованого алгоритму лікування та техніки створення анастомозу, направленого на зниження частоти післяопераційних ускладнень. 
Матеріали і методи. Фактором, що негативно впливає на розвиток ускладненого перебігу процесу загоєння товстокишкового анастомозу (TKA), $€$ внутрішньокишкова гіпертензія (ВКГ), а одним 3 найбільш ефективних заходів щодо профілактики ускладнень - трансанальне дренування. Для підтвердження цієї гіпотези і уточнення методології ведення хворих з подібним типом дренажу в клінічних умовах проведено моніторинг внутрішньокишкового тиску (ВКТ) після формування ТКА в післяопераційному періоді. Вивчено вплив ВКТ на процес загоєння рани залежно від виду ТКА і дана оцінка ефективності трансанального дренування. Для цього в групі з 30 пацієнтів вимірювали ВКТ у післяопераційному періоді. Під час операції, крім трансанального дренажу, який заводили вище анастомозу на 5-10 см, проводили трубку діаметром 0,5 см, кінець якої встановлювали на рівні ТКА. Вимірювання тиску проводили методом Вальдмана протягом 72 год з моменту операції, тобто до видалення дренажу, кожні 4 години. При цьому виконували 2 вимірювання - до і після промивання трансанального дренажу (рис. 1).

Для достовірності результатів дослідження виконано серед ідентичних за рядом ознак стомованих хворих після виконання відновних операцій. Первинною операцією у всіх була резекція сигмоподібної кишки з формуванням одноствольної колостоми. При виконанні відновного втручання TKА за розробленою методикою виконали 17, ручний дворядний ТКА - 3, апаратний ТКА - 10.

Результати досліджень та їх обговорення. Було встановлено, що в післяопераційному пері-

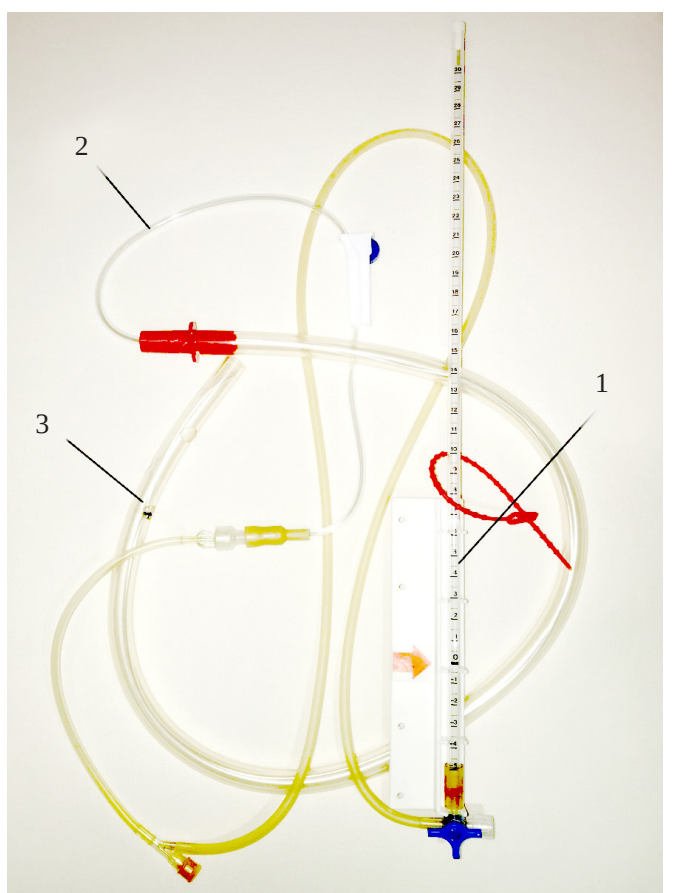

Рис. 1. Трансанальний дренаж із трубкою всередині, під’єднаною до апарата Вальдмана (1 - одноразовий апарат Вальдмана; 2 - трубка від системи зафіксована в просвіті трансанального дренажу; 3 - трансанальна дренажка трубка).

оді в ободовій кишці спостерігається зростання BKT (P) протягом перших 24-36 год (t) в середньому до 5,3 \pm 0,1 мм рт. ст., з подальшим зниженням цього рівня протягом наступних 12-20 год до (2,1 $\pm 0,3)$ мм рт. ст. (рис. 2). Через 20 хв після промивання трансанального дренажу і відходження

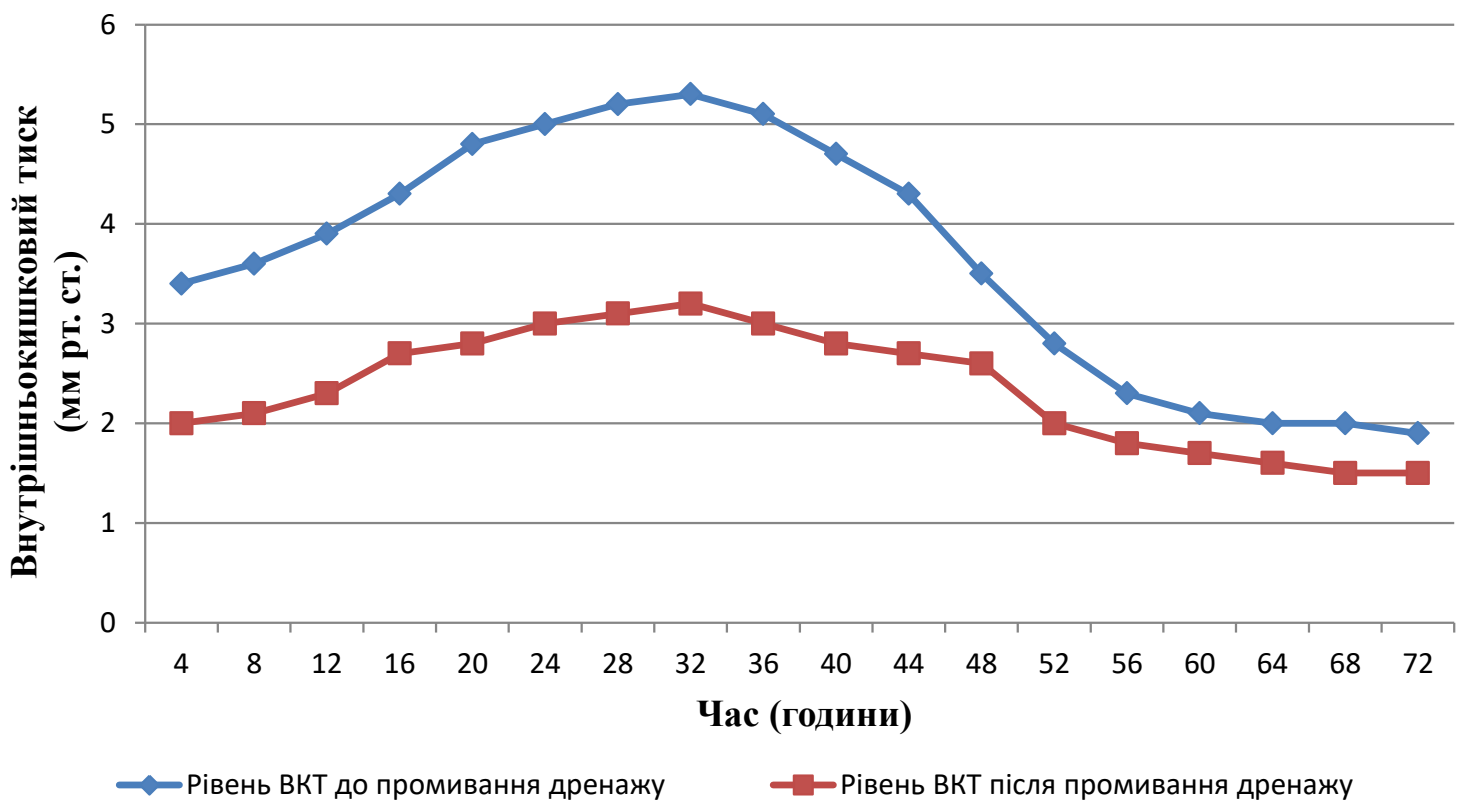

Рис. 2. Динаміка внутрішньокишкового тиску після промивання трансанального дренажу. 
“промивних вод” рівень ВКТ знижується в середньому на $(3,0 \pm 1,3)$ мм рт. ст. Це зниження утримувалося протягом 3-5 год, після чого спостерігали поступове зростання рівня ВKТ. В зв’язку з цим для підтримки декомпресійного ефекту потрібно промивання дренажу кожні 4 години.

Таким чином, встановлено, що в ранньому післяопераційному періоді ВКТ має тенденцію до підвищення до рівня $(5,3 \pm 0,1)$ мм рт. ст., для корекції якого ефективним заходом є промивання трансанального дренажу не рідше, ніж один раз на 4 години.

Наступний розділ клінічного дослідження дозволив визначити кореляційний зв'язок між рівнем ВКТ та ускладненнями загоєння анастомозу.

При застосуванні традиційного дворядного анастомозу у 2 хворих спостерігали ускладнений перебіг післяопераційного періоду. В одному спостереженні відзначена неспроможність ТKА, у другого пацієнта спостерігався анастомозит. ТКА розробленим способом виконано 17 хворим (рис. 3). Спосіб створення анастомозу у власній модифікації заключається в тому, що більш широка проксимальна частина товстої кишки інвагінується в дистальну (більш звужену) шляхом створення співгирла за типом “кінець у бік”, чим нівелюється різниця діаметрів. Перед цим на проксимальну куксу товстої кишки накладають кисетний шов, що спрощує проведення кишки в кишку, який утримують під натягом, а голку з двома кінцями лігатур від кисетного шва проводять через середину tenia liebera на відстані 5-7 см дистальніше отвору товстої кишки, утримуючи під натягом проксимальну частину. Формують анастомоз “кінець в бік” однорядним серозно-м’язовим внутрішньовузловим
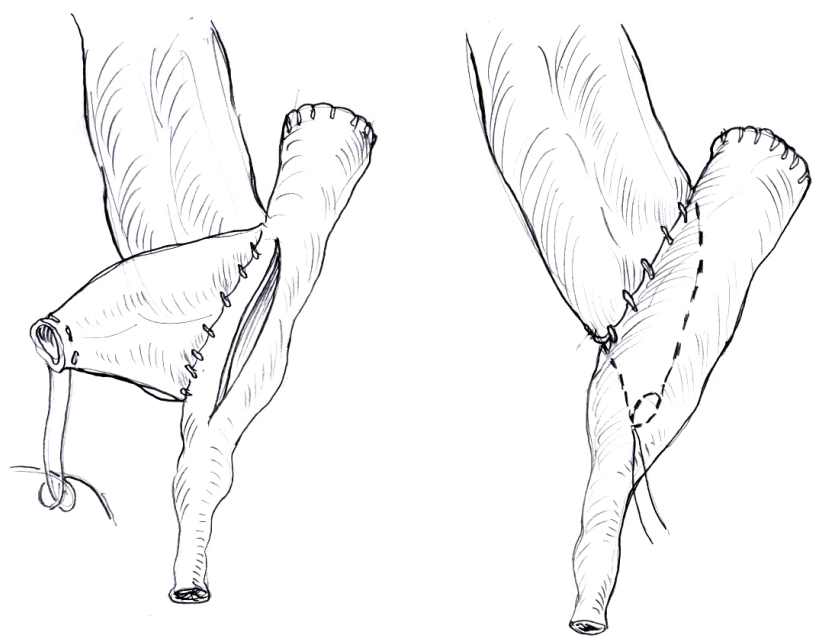

Рис. 3. Спосіб створення товсто-товстокишкового анастомозу “кінець у бік”. швом атравматичною ниткою 4/0, 5/0 без захоплення слизової, вузликами досередини швів, після чого один кінець лігатури від кисетного шва зрізають, а другий витягують, що призводить до розкриття отвору інвагінаційної частини. Апаратний ТКА застосували у 10 хворих, при цьому анастомозит розвинувся в одного пацієнта. Отже, ускладнення зустрілися переважно при застосуванні ручного традиційного шва (10 \%).

Було встановлено, що у всіх хворих з розвиненими порушеннями загоєння кишкового шва (при анастомозиті, неспроможності ТКА) спостерігається підвищення ВКТ через 16-60 год до $(11,4 \pm 0,2)$ мм рт. ст., 3 піком рівня ВКТ 16,317,1 мм рт. ст. Необхідно зазначити, що протягом всього аналізованого періоду рівень ВКТ був вище в 2-3 рази порівняно з відповідним сегментом у хворих, у яких зазначено неускладнений перебіг післяопераційного періоду. Подібна динаміка тиску спостерігалася аж до розвитку неспроможності кишкового шва, після чого спостерігали зниження ВКТ. При анастомозиті подібного різкого зниження ВКТ не було.

Важливе не тільки власне стійке підвищення BKT із критичним рівнем до 16,3-17,1 мм рт. ст., а й тривалість впливу його протягом 12-18 год. Таким чином, було встановлено, що критичний рівень внутрішньокишкової гіпертензії (ВКГ), яка призводить до розвитку ускладненого перебігу післяопераційного періоду, становить 16,517,0 мм рт. ст. протягом 12-18 год (рис. 4).

Отже, ВКГ достовірно негативно впливає на умови загоєння ран товстої кишки в післяопераційному періоді, особливо на 3-5 добу, призводячи до різкого зниження механічної міцності, створюючи умови для розвитку порушень загоєння кишкового шва. При розвитку в сегменті товстої кишки критичної за рівнем і часом ВКГ формується крайній ступінь порушення загоєння ран їх неспроможність. Критичним для товстої кишки слід вважати рівень ВКГ - 16,5-17,0 мм рт. ст. при тривалості впливу протягом 12-18 год.

Фоном для розвитку порушення загоєння, виходячи з патогенезу, є запально-некротичні зміни країв рани (анастомозу); гіпоксія, загальні порушення мікроциркуляції (крововтрата); ішемія в результаті порушення місцевого кровообігу (розрив живлячих судин, здавлювання і лігування їх багаторядними і безперервними швами, надлишкова мобілізація в стінці кишки); порушення техніки шва (наскрізний прокол стінки, грубий шовний матеріал, часте накладання швів); порушення процесів регенерації (гіпопротеїнемія, супутні захворювання). Ці фактори призводять до розви- 


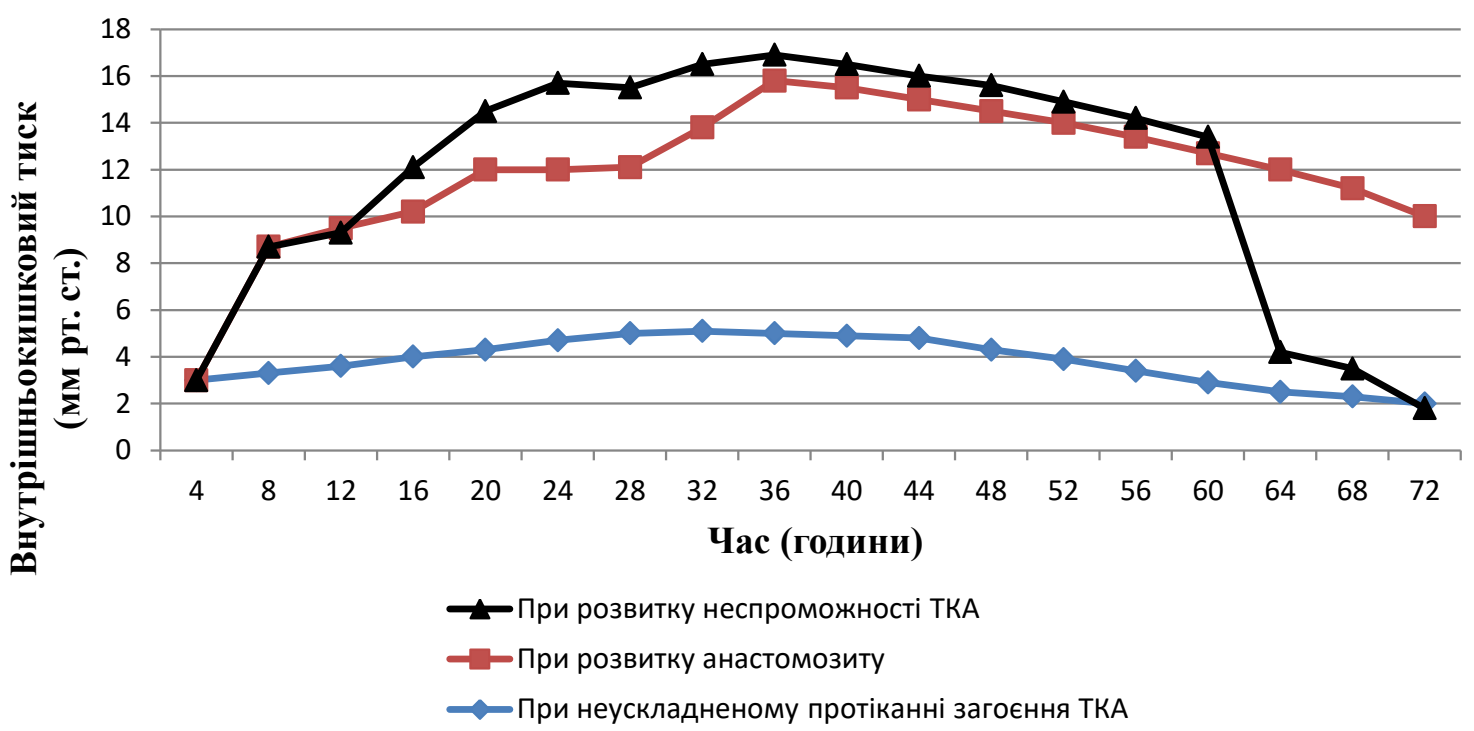

Рис. 4. Зміни внутрішньокишкового тиску при різних видах загоєння товстокишкового анастомозу.

тку інфільтративного або гострого гнійного анастомозиту в перші 3-5 діб післяопераційного періоду. Посилення на цьому фоні післяопераційної ВКГ визначає наступну динаміку загоєння анастомозів. При інфільтративному анастомозиті вплив ВКГ посилює порушення мікроциркуляції з поглибленням ішемії в зоні шва. Розвивається депресія місцевих факторів протиінфекційного захисту, яка призводить до прогресування запально-деструктивних процесів. Безпосереднім результатом вищеперерахованих процесів є різке зниження механічної міцності [1-4].

Таким чином, значення ВКГ у розвитку порушення загоєння кишкового шва безсумнівне. Некорегована ВКГ знижує механічну міцність анастомозів. Це призводить до розвитку анастомозиту або неспроможності кишкового шва.

Вирішальним патогенетичним фактором у розвитку порушення загоєння кишкового шва $€$ ступінь коливань, з формуванням стійкої ВКГ і розвитком його критичного рівня. Саме ця послідовність в патогенезі визначає розвиток неспроможності кишкового анастомозу. Сприятливими факторами для порушення загоєння кишкового шва, який реалізується внаслідок формування стійкої ВКГ і розвитку критичного рівня ВКГ, являються як загальні, так і місцеві фактори.

Загальні порушення пов'язані з основним захворюванням, ступенем компенсації органів і систем, порушенням гомеостазу, імунітету, репаративними можливостями і т. п. Місцеві належить безпосередньо до зони анастомозу та характеризуються видом анастомозу, вираженістю запалення, ступенем порушення мікроциркуляції, підготовленістю кишечника до операції. Проте роль
ВКТ, динаміка зміни його рівня і розвиток ВКГ, що визначає прогноз перебігу процесу загоєння рани, найбільш значима, що показано проведеними експериментально-клінічними дослідженнями $[1,4]$. При цьому зниження реальної механічної міцності і біологічної герметичності відбувається $з$ плином часу (t) від моменту операції - P (t). На характер і темп цього процесу впливає рівень BKT, що підвищується при несприятливому поєднанні сприяючих факторів: прогресуючому запаленні, погіршенні мікроциркуляції, інфікуванні лінії анастомозу, зниженні місцевого імунітету. При неефективності профілактичних заходів ВКТ досягає критичного рівня і призводить до неспроможності анастомозу та інших ускладнень [4-6].

Розробка комплексної програми профілактичних заходів будується з огляду на концепції патогенезу порушення загоєння кишкового шва.

Заходи, що забезпечують зниження ВКГ, включають прямі (інтубація кишечника, трансанальне зондування) і непрямі (блокади, застосування лікарських препаратів, фізіолікування) методи декомпресії. Заходи, що підвищують якісні характеристики кишкового шва, полягають у розробці способу формування товстокишкового анастомозу, який забезпечує високий рівень механічної міцності і біологічної герметичності. Це досягається застосуванням прецизійної техніки операції і сучасного електрообладнання при мобілізації сегментів кишки, що анастомозуються, використанням атравматичного шовного матеріалу, формуванням анастомозу однорядним внутрішньовузликовим швом, зміцненням лінії швів пластиною Тахокомб або чепцем, створенням локального депо антибіотика або використанням апаратного шва [3, 4]. 
Все це визначає необхідність оцінки наявних та розробці нових способів корекції ВКГ і заходів щодо підвищення якісних характеристик кишкового анастомозу [4].

\section{СПИСОК ЛІТЕРАТУРИ}

1. Агаев Э. К. Несостоятельность швов кишечных анастомозов у больных после экстренной и неотложной резекции кишки / Э. К. Агаев // Хирургия. Журнал им. Н. И. Пирогова. 2012. - № 1. - С. 34-37.

2. Березницький Я. С. Обгрунтування виконання первинновідновних оперативних втручань при обструктивній непрохідності ободової кишки // Я. С. Березницький, А. В. Гапонов, В. М. Турчин // Український журнал хірургії. - 2009. № 5. - С. 11-13.

3. Восстановительные операции в хирургии толстой кишки / М. П. Захараш, А. И. Пойда, В. М. Мельник [и др.] // Матеріали II з'їзду колопроктологів України за міжнародною участю, 1-2 листопада 2006 р. - К. : Медицина, 2006. - С. 403-405.

4. Способ профилактики несостоятельности анастомоза по-
Висновок. Стійке підвищення ВКТ з критичним його рівнем 16,3-17,1 мм рт. ст. протягом 1218 годин призводить до розвитку ускладненого перебігу післяопераційного періоду. сле передних резекций прямой кишки и реконструктивновосстановительных операций / 3. В. Тотиков, В. 3. Тотиков, А. К. Качмазов [и др.] // Кубанский научный медицинский вестник. - 2013. - № 4 (139). - С. 109-111.

5. Dinning P. G. The use of colonic and anorectal high-resolution manometry and its place in clinical work and in research / P. G. Dinning, E. V. Carrington, S. M. Scott / Neurogastroenterol Motil. - 2015. - Vol. 27 (12). - P. 1693-1708.

6. Shogan B. D. Do we really know why colorectal anastomoses leak? / B. D. Shogan // Journal of Gastrointestinal Surgery. 2013. - No. 17 (9). - P. 1698-1707.

7. Siegel R. Colorectal cancer statistics 2014 / R. Siegel, C. DeSantis, A. Jemal // CA: A Cancer Journal for Clinicians. 2014. - No. (64) 2. - P. 104-117.

\section{REFERENCES}

1. Agaev, E.K. (2012). Nesostoyatelnost shvov kishechnykh anastomozov u bolnykh posle ekstrennoy i neotlozhnoy rezektsii kishki [Anastomotic failure after urgent bowel resection]. Khirurgiya. Zhurnal im. N.I. Pirogova - Surgery. Journal named after N.I. Pirogov, 1, 34-37 [in Russian].

2. Bereznytskyi, Ya.S., Haponov, A.V., \& Turchyn, V.M. (2009). Obhruntuvannia vykonannia pervynno-vidnovnykh operatyvnykh vtruchan pry obstruktyvnii neprokhidnosti obodovoi kyshky [Reasoning of primary-reconstructive operations after large bowel obstruction]. Ukrainskyi Zhurnal Khirurhii - Ukrainian Jornal of Surgery, 5, 11-13 [in Ukrainian].

3. Zakharash, M.P., Poida, A.I., Melnik, V.M. (2006). Vosstanovitelnye operatsii $\mathrm{v}$ khirurgii tolstoy kishki [Reconstructive operations in colon surgery]. Materiali II zizdu koloproktolohiv Ukrainy za mizhnarodnoiu uchastiu - Materials of the II Congress of Coloproctologists of Ukraine with International Participation, (pp. 403-405). [in Russian].
4. Totikov, Z.V., Totikov, V.Z., Kachmazov, A.K., Medoedov, V.V., Kalitsova, M.V., \& Malsagov, R.Yu. (2013). Sposob profilaktiki nesostoyatelnosti anastomoza posle perednikh rezektsiy pryamoy kishki i rekonstruktivno-vosstanovitelnykh operatsiy [Method of prevention of anastomotic failure after rectum resetion and reconstructive operations]. Kubanskiy nauchnyy meditsinskiy vestnik - Kuban Scientific Medical Journal, 4, 109-111 [in Russian]. 5. Dinning, P.G., Carrington, E.V., \& Scott, S.M. (2015). The use of colonic and anorectal high-resolution manometry and its place in clinical work and in research. Neurogastroenterology \& Motility, 27 (12), 1693-1708.

6. Shogan, B.D., Carlisle, E.M., Alverdy, J.C., \& Umanskiy, K. (2013). Do we really know why colorectal anastomoses leak? Journal of Gastrointestinal Surgery, 17 (9), 1698-1707.

7. Siegel, R., DeSantis, C., \& Jemal, A. (2014). Colorectal cancer statistics, 2014. CA: A Cancer Journal for Clinicians, 64 (2), 104-117.

\section{INTRACOLONIC PRESSURE AT RECONSTRUCTIVE-RESTORATIVE SURGERY IN OSTOMY PATIENTS}

\footnotetext{
The aim of the work: to improve treatment outcomes in patients with surgical pathology of the colon by working-out and implementing pathogeneticly grounded treatment algorithm and anastomosis creation technology, aimed at reducing the frequency of postoperative complications.

Materials and Methods. The intracolonic pressure (ICP) was measured in the postoperative period in a group of 30 patients. During the operation, except transanal drainage, which was located higher from anastomosis by $5-10 \mathrm{~cm}$, was inserted a tube with diameter of $0.5 \mathrm{~cm}$., which end was located at large intestine anastomosis (LIA). Pressure measurement was performed by Waldman method within 72 hours
} 
after the operation, every 4 hours. There were performed 2 measurements - before and after lavage of transanal drainage. During performing reconstructive operation worked-out LIA technique was performed 17 times, two-row suture manual LIA - 3, machine LIA -10.

Results and Discussion. It was found that in the postoperative period the ICP was increasing during the first 24-36 hours to an average of $(5.3 \pm 0.1) \mathrm{mm} \mathrm{Hg}$, with a further reduction of it’s level over the next 12-20 hours to $(2.1 \pm 0.3) \mathrm{mm} \mathrm{Hg}$. In 20 minutes after the lavage of transanal drainage the ICP reduced by an average of $(3.0 \pm 1.3) \mathrm{mm}$ Hg. This decreasing was detained for $3-5$ hours, then was noticed a gradual increasing of ICP. In case of using traditional two-row suture anastomosis in 2 patients was noticed complicated postoperative period - the anastomotic leakage in one patient, the second had anastomositis. Worked-out LIA technique was used in 17 patients, machine LIA - in 10 patients, while anastomositis developed in 1 patient. It was found that in all patients with disorders of suture wound healing was marked the increasing of ICP after 16-60 hours to (11.4 \pm 0.2$) \mathrm{mm} \mathrm{Hg}$, with a peak of ICP (16.3-17.1) mm Hg. This dynamic of pressure was observed until the development of intestinal suture failure (anastomotic leakage), with a reduction of ICP after it. In patients with anastomositis such a reduction of ICP wasn't noticed. It had importance not only the increasing the level of pressure 16.3-17.1 mm Hg, but it’s duration for 12-18 hours.

Key words: intracolonic pressure; large intestine anastomosis; reconstructive operation; stoma.

\author{
В. И. РУСИН, С. М. ЧОБЕЙ, А. А. ДУТКО
}

гВУз “Ужгородский национальный университет”

\title{
ВНУТРИКИНЕЧНОЕ ДАВЛЕНИЕ ПРИ РЕКОНСТРУКТИВНО-ВОССТАНОВИТЕЛЬНЫХ ОПЕРАЦИЯХ У СТОМИРОВАННЫХ БОЛЬНЫХ
}

Цель работы: улучшение результатов лечения больных с хирургической патологией ободочной кишки путем разработки и внедрения патогенетически обоснованного алгоритма лечения и техники создания анастомоза, направленного на снижение частоты послеоперационных осложнений.

Материалы и методы. В группе из 30 пациентов измеряли внутрикишечное давление (ВКД) в послеоперационном периоде. Во время операции, кроме трансанального дренажа, который заводили выше анастомоза на 5-10 см, проводили трубку диаметром 0,5 см, конец которой устанавливали на уровне толстокишечного анастомоза (ТKА). Измерение давления проводили методом Вальдмана в течение 72 ч с момента операции, каждые 4 часа. Выполняли 2 измерения - до и после промывания трансанального дренажа. При выполнении восстановительного вмешательства ТКА по разработанной методике выполнили - у 17, ручной двухрядный ТКА - 3, аппаратный ТКА - 10 пациентов.

Результаты исследований и их обсуждение. Установлено, что в послеоперационном периоде в ободочной кишке отмечается рост ВКД в течение первых 24-36 ч в среднем до $(5,3 \pm 0,1)$ мм рт. ст., с последующим снижением его в течение следующих $12-$ 20 ч. до $(2,1 \pm 0,3)$ мм рт. ст. Через 20 мин после промывания трансанального дренажа уровень ВКД снижается в среднем на $(3,0 \pm$ 1,3) мм рт. ст. Это снижение удерживалось в течение 3-5 ч, после чего отмечено постепенное увеличение ВКД. При применении традиционного двухрядного анастомоза у 2 больных отмечено несостоятельность ТКА у 1 пациента, у второго - анастомозит. TKА разработанным способом выполнено 17 больным, аппаратный ТКА применили у 10 больных, при этом анастомозит развился у одного пациента. Осложнения наблюдали преимущественно при применении ручного традиционного шва (10 \%). У всех больных с развитыми нарушениями заживления кишечного отмечается повышение ВКД через $16-60$ ч до $(11,4 \pm 0,2)$ мм рт. ст., с пиком уровня ВКД 16,3-17,1 мм рт. ст., что наблюдалась вплоть до развития несостоятельности анастомоза, с последующим резким снижением ВКД. При анастомозите подобного снижения ВКД не было. Имело значение не только устойчивое повышение ВКД с критическим уровнем до 16,3-17,1 мм рт. ст., но и продолжительность воздействия его в течение 12-18 ч.

Ключевые слова: внутрикишечное давление; толстокишечный анастомоз; реконструктивная операция; стома. 